Jurnal geoedusains, Volume 2, Nomor 1, Juni 2021

\title{
Pola dan Struktur Ruang Kelurahan Bulukunyi Sebagai Ibukota Kecamatan Polongbangkeng Selatan Kabupaten Takalar
}

\author{
Muhammad Husain Hasan ${ }^{1}$ \\ Jurusan Pendidikan Geografi FKIP Undana Kupang \\ Korespondensi: muhammadhusain@staf.undana.ac.id
}

\begin{abstract}
Abstrak
Kelurahan merupakan region politis setingkat desa di bawah kecamatan yang dipimpin oleh seorang lurah. Dalam sejarah perkembangannya, Kelurahan Bulukunyi pernah berstatus sebagai desa hingga akhirnya beralih status menjadi kelurahan. Tujuan dari penelitian ini adalah untuk mengkaji struktur dan pola keruangan Kelurahan Bulukunyi sebagai ibukota kecamatan sehingga diperoleh gambaran tentang struktur dan arah perkembangan region tersebut. Metode penelitian yang digunakan adalah deskriptif kualitatif. Teknik pengumpulan data adalah triangulasi dengan analisis foto udara dan survey lapangan. Data yang terkumpul akan dianalisis secara deskriptif kualitatif meliputi reduksi dan kategorisasi data, display data, dan penarikan kesimpulan. Hasil Penelitian menunjukkan: 1). Permukiman penduduk dan pusat-pusat kegiatan di Kelurahan Bulukunyi berpola teratur atau sejajar dengan jalan dengan pengembangannya mengikuti keberadaan jalur transportasi; 2). Fasilitas publik cukup tersedia antara lain fasilitas perkantoran, kesehatan, ekonomi, pendidikan, dan ibadah; 4). Penggunaan lahan masih didominasi lahan pertanian.
\end{abstract}

Kata Kunci: Pola Ruang, Struktur Ruang, Kelurahan Bulukunyi, Ibukota Kecamatan

\section{Pattern And Spatial Structure Of Kelurahan Bulukunyi As The Capital Of South Polongbangkeng District Takalar Regency}

\begin{abstract}
Abstrack
Kelurahan were a political region as level as village below the district which was governed by a lurah. In the history of its development, Kelurahan Bulukunyi had the status of a village until finally it changed its status became a kelurahan. The aim of this research were to examine the spatial structure and pattern of the Kelurahan Bulukunyi as the capital of the district in order to obtain an overview of the structure and direction of development of the region. The research method used was descriptive qualitative. Technique of data collection was triangulation with analysis of aerial imagery and field surveys. The collected data will be analyzed by descriptive qualitatively including data reduction and categorization, data display, and conclusions. The results showed: 1). Residential settlements and activity centers in Kelurahan Bulukunyi were regularly patterned or parallel to roads with
\end{abstract}


development following the existence of transportation routes; 2). Sufficiently available public facilities include office facilities, health, economy, education, and worship; 4). The land used was still dominated by agricultural land used.

Keyword: Spatial Pattern, Spatial Structure, Kelurahan Bulukunyi, Capital of District

\section{Pendahuluan}

Objek studi yang dipelajari oleh geografi adalah semua gejala atau fenomena yang terdapat di permukaan bumi. Gejala/fenomena/realitas merupakan kenampakan-kenampakan objek yang terdapat pada ruang muka bumi (Prasad, 2013: 15). Ruang di permukaan bumi meliputi ruang darat, ruang laut dan ruang udara sebagai satu kesatuan wilayah, tempat manusia dan makhluk lain hidup beraktivitas untuk kelangsungan hidupnya. Menurut Yunus (2010: 47), gejala/fenomena geografi dari segi ekspresi keruangannya dibedakan atas: 1). Gejala fisik, yaitu gejala yang eksistensinya menunjukkan bentuk yang dapat disentuh secara fisik seperti jalan, gedung, sungai, danau, tanah; dan 2). Gejala non fisik yaitu gejala yang tidak dapat disentuh secara fisik seperti persepsi, bahasa, tingkat pendidikan, agama dan sebagainya. Menurut Alfandi (2001: 71), kajian atau penelitian keruangan berkisar pada:

1. Fakta pola pemanfaatan ruang yang sekarang ada;

2. Keuntungan dan kelemahan lokasi yang strategis;

3. Faktor yang mempengaruhi pola penyebaran obyek penelitian;

4. Intervensi agar pola penyebaran tersebut dapat lebih efisien.

Struktur ruang didefinisikan sebagai susunan pusat-pusat permukiman, sistem jaringan serta sistem prasarana maupun sarana yang berfungsi sebagai pendukung aktivitas penduduk dan saling terhubung secara fungsional. Struktur akan selalu berubah seiring dengan pertumbuhan secara sosial-ekonomi penduduknya. Menurut Yunus (2010: 56), struktur ruang adalah wadah gejala geosfera yang di dalamnya terdapat berbagai macam gejala baik gejala fisik maupun non fisik. Selanjutnya Schnore (Surachman, 2012: 1), mengemukakan bahwa struktur terbentuk beradasarkan persebaran kegiatan secara spasial. Struktur akan terbentuk dan berkembang menyesuaikan dengan pusat-pusat permukiman, aksesibilitas transportasi, dan sarana-prasarana pendukung aktivitas sosial ekonomi penduduk. Region merupakan bagian permukaan bumi dengan karakteristik khas yang 
membedakannya dengan bagian permukaan bumi lainnya. Vidal (Suharyono, 2013: 172) mengemukakan bahwa wilayah muka bumi dapat digolongkan atas kawasankawasan yang jelas pembagiannya. Desa dan kota merupakan dua region dengan karakteristik berbeda namun saling membutuhkan. Tarigan (2005: 160) mengemukakan bahwa ada tiga jenis hubungan antara kota dengan daerah di belakangnya termasuk desa/kelurahan yaitu sebagai berikut:

1. Kota generatif, kota ini dapat menjalankan bermacam-macam fungsi diantaranya menyerap/memasarkan produksi dari daerah pedalaman sekaligus dapat memenuhi kebutuhan daerah pedalaman berupa produk yang dihasilkan di perkotaan.

2. Kota parasitif, kota ini tidak banyak berfungsi menolong daerah belakangnya bahkan bisa mematikan usaha yang mulai berkembang di desa. Industrinya belum berkembang bahkan cenderung duplikatif dengan usaha di desa serta belum mampu menampung hasil produk dari desa.

3. Kota tertutup (enclave), kota ini tidak mengharapkan input dari daerah sekitarnya melainkan dari daerah luar.

Yunus (2010: 116) mengklasifikasi bentuk interelasi antar komponen wilayah sebagai berikut:

1. Keterkaitan aksial, keterkaitan antar komponen dimana salah satu mempengaruhi yang lain sedangkan yang lain tidak mempengaruhinya.

2. Keterkaitan interaksial, keterkaitan antar komponen dimana komponenkomponen tersebut saling mempengaruhi satu sama lain.

3. Keterkaitan dependensial, keterkaitan antar komponen yang menunjukkan derajat intensitas yang lebih tinggi dibandingkan dengan aksial. Contoh komponen $A$ benar-benar bergantung pada komponen $B$ sementara komponen $\mathrm{B}$ tidak bergantung pada komponen $\mathrm{A}$.

4. Keterkaitan interdependensial, bentuk keterkaitan dimana masing-masing komponen benar-benar bergantung satu sama lain.

Desa/kelurahan merupakan wilayah/region administratif dengan teritorial yang telah ditetapkan secara yuridis. Menurut Undang Undang No. 32 Tahun 2004 tentang Pemerintah Daerah, Desa adalah kesatuan masyarakat hukum yang memiliki batas-batas wilayah yang berwenang untuk mengatur dan mengurus kepentingan masyarakat setempat, berdasarkan asal-usul dan adat istiadat 
setempat yang diakui dan dihormati dalam sistem Pemerintahan Negara Kesatuan Republik Indonesia. Dalam Peraturan Pemerintah Nomor 72 dan 73 Tahun 2005 dijabarkan tentang definisi desa dan kelurahan sebagai berikut: 1). Desa adalah kesatuan masyarakat hukum yang memiliki batas-batas wilayah yang berwenang untuk mengatur dan mengurus kepentingan masyarakat setempat yang diakui dan dihormati dalam sistem pemerintahan NKRI; 2). Kelurahan adalah wilayah kerja lurah sebagai perangkat daerah kabupaten/kota dalam wilayah kerja kecamatan. Kelurahan memiliki masyarakat lebih heterogen dan sangat longgar dalam norma adat istiadat. Kelurahan tidak memiliki otonomi karena sebagai perangkat daerah kabupaten/kotanya memiliki kewenangan administratif dalam bentuk penetapan keputusan kepala kelurahan.

Beberapa desa yang ditetapkan sebagai ibukota kecamatan dalam perkembangannya beralih status menjadi kelurahan. Dalam hal ini karakteristik kelurahan di luar kota berbeda dengan kelurahan-kelurahan yang berada di pinggiran kota ataupun di dalam kota. Menurut Muta'ali (2016: 61), kelurahan di luar kota secara geografis berada jauh dari kota maupun pengaruh kota namun memiliki aksesibilitas yang baik sehingga memungkinkan terjadinya hubungan desa-kota atau rural-urban linkages yang lancar dan sangat mempengaruhi perkembangan keduanya.

Karakteristik keruangan desa/kelurahan bervariasi sesuai dengan kondisi geografisnya. Menurut Coffey (Yunus, 2010: 52), spesifikasi sebaran terdiri dari pola sebaran teratur, pola sebaran acak, dan pola sebaran mengelompok. Pola sebaran permukiman umumnya mengikuti kondisi geografis di wilayah tersebut. Perdesaan di kawasan pesisir dan dataran rendah umumnya mengalami perubahan tutupan lahan yang lebih cepat dibandingkan perdesaan di pegunungan (Rudiarto, dkk. 2017: 280).

Kelurahan Bulukunyi merupakan ibu kota dari Kecamatan Polongbangkeng Selatan. Kecamatan ini merupakan salah satu kecamatan di Kabupaten Takalar, Provinsi Sulawesi Selatan. Letaknya berada di bagian Timur dan berbatasan langsung dengan Kabupaten tetangga yaitu Kabupaten Jeneponto. Secara administratif, Kelurahan Bulukunyi terdiri dari lima lingkungan yaitu Lingkungan Tengko, Lingkungan Ujungbori', Lingkungan Makammu I, Lingkungan Makammu II, Lingkungan Batumaccing, dan Lingkungan Parangla'bua. 
Jurnal geoedusains, Volume 2, Nomor 1, Juni 2021

\section{Metodologi}

Metode penelitian yang digunakan adalah penelitian survey dengan pendekatan deskriptif kualitatif. Data dikumpulkan dengan teknik triangulasi. Instrumen yang digunakan adalah citra/foto udara hasil perekaman aplikasi SAS Planet Mei 2021 serta catatan lapangan untuk melakukan observasi pencocokan kenampakan pada citra dan keadaan di lokasi. Data yang diperoleh akan dikategorisasi untuk memperoleh gambaran pola dan struktur keruangan di lokasi penelitian. Analisis data dilakukan dengan mencocokkan kenampakan pada citra dengan kondisi nyata di lapangan untuk melihat pola dan struktur keruangan serta arah perkembangannya. Langkah-langkah analisis data yaitu reduksi dan kodefikasi data, penyajian data, dan penarikan kesimpulan.

\section{Pembahasan}

Perkembangan suatu region sangat ditentukan salah-satunya oleh aksesibilitas atau keterjangkauannya. Aksesibilitas memungkinkan terhubungnya suatu region dengan region lainnya. Menurut Farida (2013: 49), aksesibilitas di perdesaan merupakan faktor yang dapat merangsang tumbuhnya pusat perekonomian. Keterjangkauan dan keterhubungan akan memungkinkan berkembangnya berbagai bidang. Magribi (2004: 149) menyatakan bahwa peningkatan variabel aksesibilitas akan meningkatkan variabel pembangunan, pendapatan perkapita masyarakat, dan mobilitas di suatu lokasi.

Akses jalan yang menghubungkan Kelurahan Bulukunyi dengan desa lain maupun dengan ibukota kabupaten cukup baik. Kategori jalan termasuk jalan kolektor yang terhubung ke jalan arteri (jalan provinsi) meskipun jarak dari ibukota kabupaten cukup jauh. Pada peta berikut ditampilkan posisi Kelurahan Bulukunyi sebagai ibukota Kecamatan Polongbangkeng Selatan dan aksesnya ke berbagai ibukota kecamatan lainnya serta dengan ibukota kabupaten yaitu Kecamatan Pattallassang. 


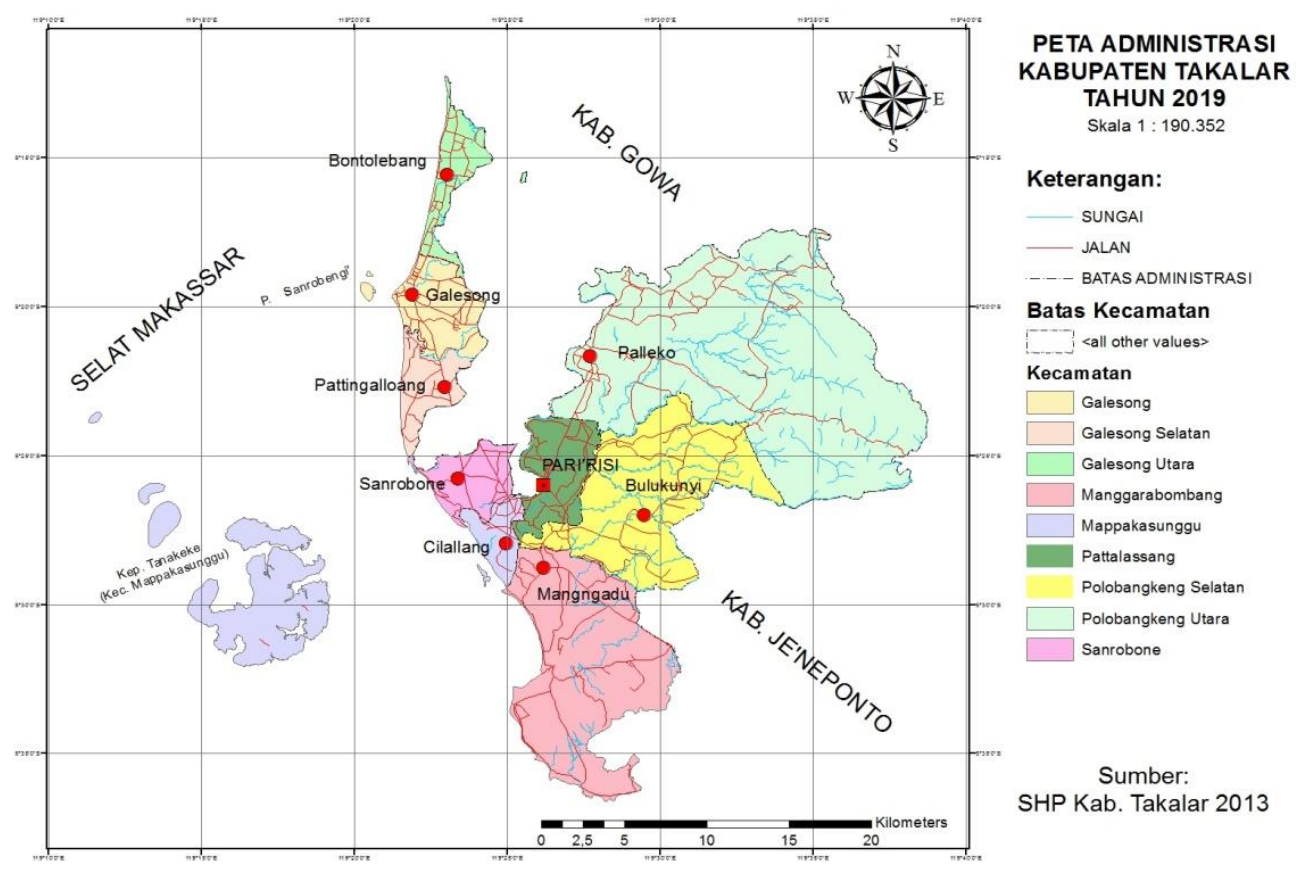

Sumber: SHP Kabupaten Takalar 2013

Gambar 1. Posisi Kelurahan Bulukunyi pada Peta Kabupaten Takalar dan aksesibilitasnya

Pola keruangan Kelurahan Bulukunyi dapat dianalisis dengan menggunakan foto udara. Pola permukiman di Kelurahan Bulukunyi menunjukkan pola memanjang (linier) mengikuti jalan utama maupun jalan lokal/jalan lain. Berikut adalah foto udara yang menampilkan Kelurahan Bulukunyi dengan berbagai kenampakan spasialnya:

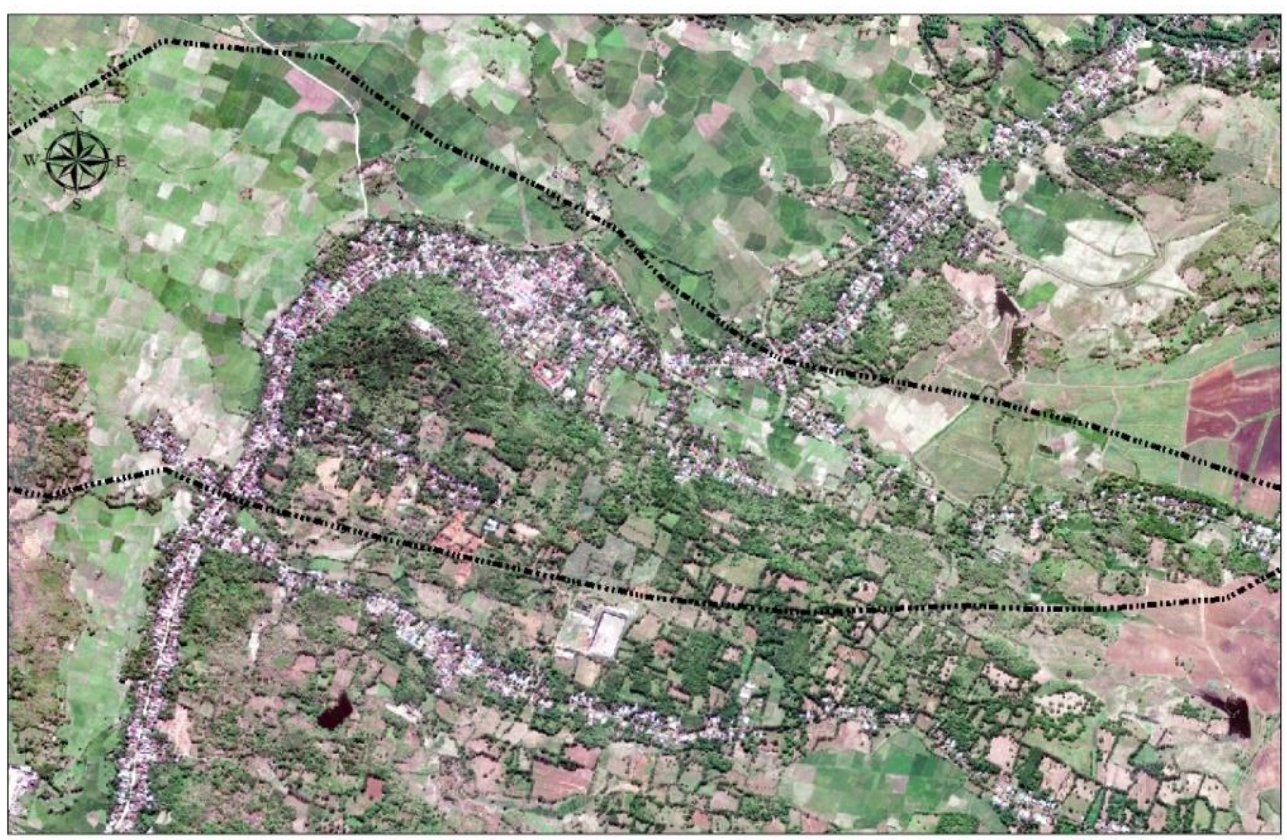

Sumber: Citra SAS Planet, Mei 2021

Pola Dan Struktur Ruang... 
Gambar 2. Foto Udara Kelurahan Bulukunyi

Sebaran permukiman penduduk di Kelurahan Bulukunyi memiliki pola teratur mengikuti jalan utama maupun jalan lokal. Pola ini dapat pula dikategorikan sebagai desa/kelurahan linier di dataran rendah. Berdasarkan analisis foto udara dan survey lapangan diperoleh gambaran bahwa permukiman penduduk dan pusat-pusat kegiatan di Kelurahan Bulukunyi umumnya sejajar dengan jalan dan pola pengembangannya mengikuti keberadaan jalur transportasi. Pada peta berikut disajikan informasi sebaran permukiman penduduk pada skala 1:20.000 yang disimbolkan dengan sebaran titik. Satu simbol titik mewakili 5 buah rumah. Dengan demikian dapat diamati distribusi rumah dan kepadatannnya .

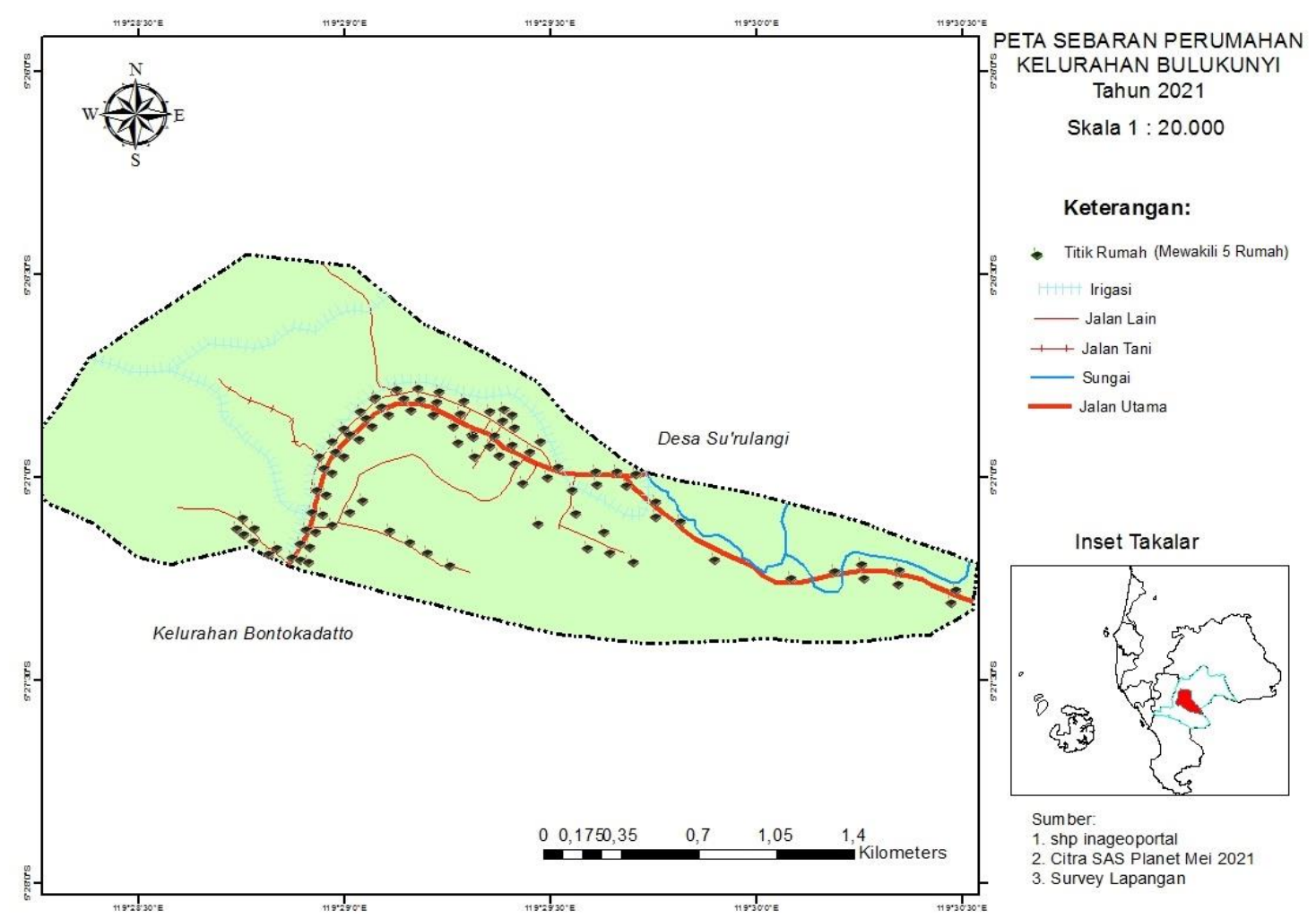

Sumber: Citra SAS Planet dan Survey Lapangan Mei 2021

Gambar 3. Peta Sebaran Perumahan Keurahan Bulukunyi

Permukiman lama berada di sekitar jalan utama sementara permukimanpermukiman baru akan meluas mengikuti akses jalan lokal. Permukiman terpadat berada pada bagian tengah dimana di area tersebut merupakan pusat kegiatan seperti perkantoran, sarana pendidikan, pasar, puskesmas, Mesjid, dan sebagainya. 
Distribusi permukiman semakin berkurang di bagian timur yang mengarah ke luar wilayah kelurahan menuju ke Kabupaten Jeneponto.

Sebagai ibu kota kecamatan, Kelurahan Bulukunyi didukung dengan ketersediaan fasilitas layanan publik yang cukup memadai. Berikut ini adalah data distribusi fasilitas layanan publik di setiap lingkungan:

Tabel 1. Distribusi Ketersediaan Fasilitas Publik Kelurahan Bulukunyi

\begin{tabular}{cc}
\hline No. & Jenis Fasilitas Publik \\
\hline 1. & Sekolah \\
\hline 2. & Puskesmas \\
\hline 3. & Mesjid \\
\hline 4. & Pasar \\
\hline 5. & Kolam Renang \\
\hline 6. & Lapangan Olahraga \\
\hline 7. & Tempat Pemakaman Umum \\
\hline 8. & Monumen (Situs Sejarah) \\
\hline 9. & Kantor Pemerintahan (Camat dan Lurah) \\
\hline 10. & Jalan Tani \\
\hline 11. & Saluran Irigasi \\
\hline
\end{tabular}

Sumber: Survey Lapangan, Mei 2021

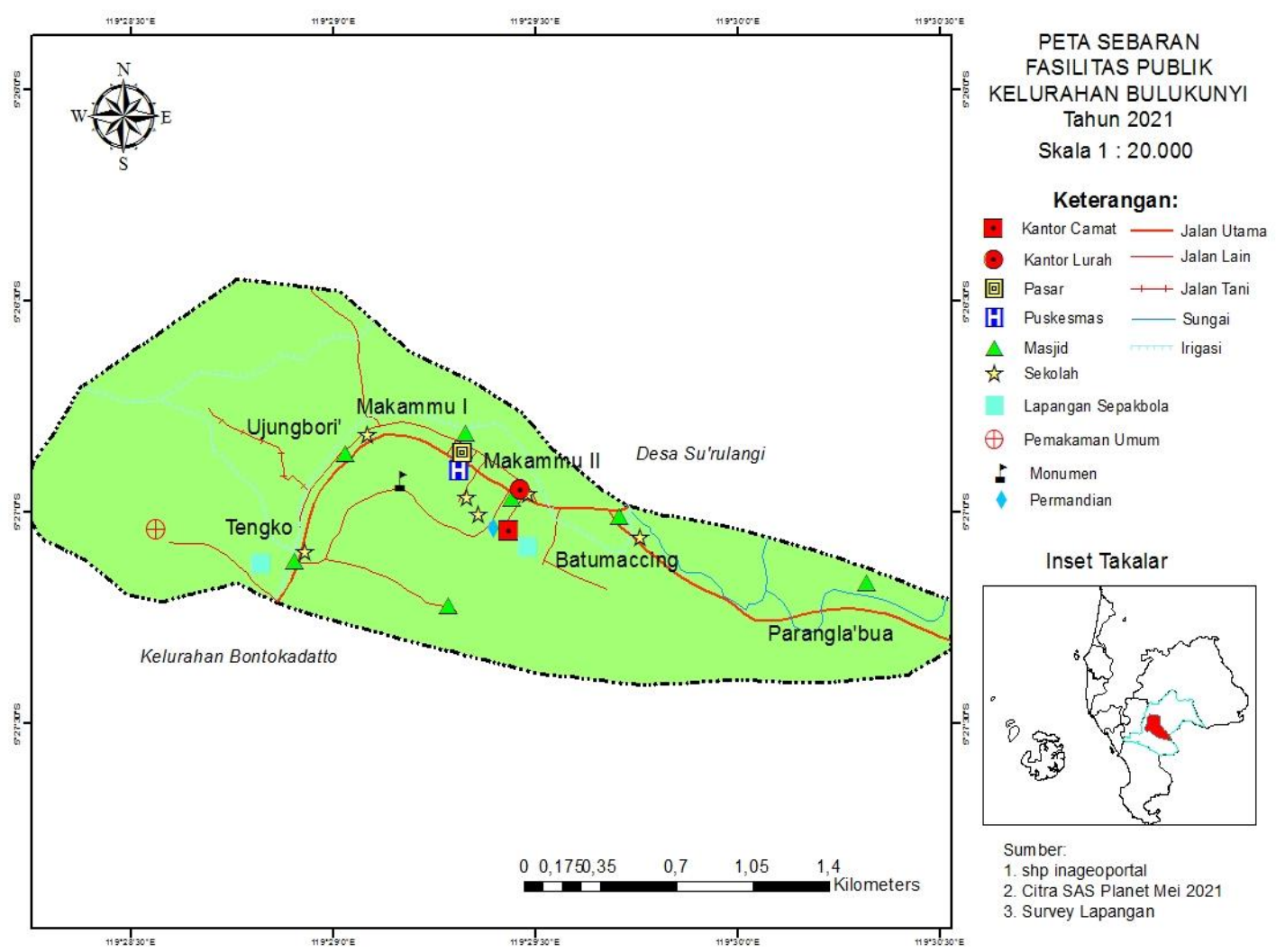

Sumber: Citra SAS Planet dan Survey lapangan, Mei 2021

Gambar 4. Peta Sebaran Fasilitas Publik Kelurahan Bulukunyi 
Berdasarkan hasil survey, keadaan fasilitas layanan publik di Kelurahan Bulukunyi adalah sebagi berikut:

1. Jaringan Jalan (Aksesibilitas). Sistem jaringan jalan di Kelurahan Bulukunyi sudah dapat menghubungkan pusat layanan dengan pusat-pusat lainnya. Seluruh lingkungan (setingkat dusun) dapat terjangkau. Jalan utama berupa jalan kolektor dapat terakses ke jalan nasional (jalan arteri) sedangkan untuk beberapa pelosok permukiman dapat diakses melalui jalan lokal. Selain itu, untuk kepentingan aktivitas pertanian juga telah dibuat jalan tani yang dapat terakses ke areal persawahan.

2. Pusat Perkantoran. Fasilitas perkantoran secara umum sudah cukup untuk melayani kebutuhan pelayanan di Kelurahan Bulukunyi. Kantor Camat dan Kantor Kelurahan berada pada lokasi yang berdekatan memungkinkan untuk kemudahan pelayanan administrasi warga.

3. Fasilitas Pendidikan. Fasilitas pendidikan di Kelurahan Bulukunyi tersebar di tiap lingkungan terdiri dari Sekolah Dasar (SD) sebanyak 3 buah, Sekolah Menengah Pertama (SMP) sebanyak 1 buah, Madrasah Tsanawiyah (MTs) sebanyak 1 buah, dan Madrasah Aliyah (MA) sebanyak 1 buah. Total fasilitas pendidikan formal sebanyak 6 buah.

4. Fasilitas Kesehatan. Di Kelurahan Bulukunyi terdapat sebuah Puskemas yang dapat melayani masyarakat di beberapa desa.

5. Fasilitas rumah ibadah. Di Kelurahan Bulukunyi terdapat sejumlah Mesjid yang tersebar di setiap lingkungan. Total jumlah mesjid di Kelurahan Bulukunyi adalah 7 buah.

6. Pasar. Sebagai sarana pendukung aktivitas perekonomian masyarakat, di Kelurahan Bulukunyi terdapat sebuah pasar yang buka sebanyak dua kali dalam seminggu.

7. Fasilitas pendukung lainnya, berupa lapangan sepakbola sebanyak 2 buah, tempat pemakaman umum satu buah dan sebuah situs sejarah perjuangan berupa Monumen di puncak bukit.

Distribusi penggunaan lahan di Kelurahan Bulukunyi terdiri dari permukiman, persawahan, perkebunan, hutan, dan lahan kosong/belukar. Persentasi penggunaan lahan terbanyak adalah persawahan dimana mayoritas penduduk Kelurahan Bulukunyi berprofesi sebagai petani sawah tadah hujan. 


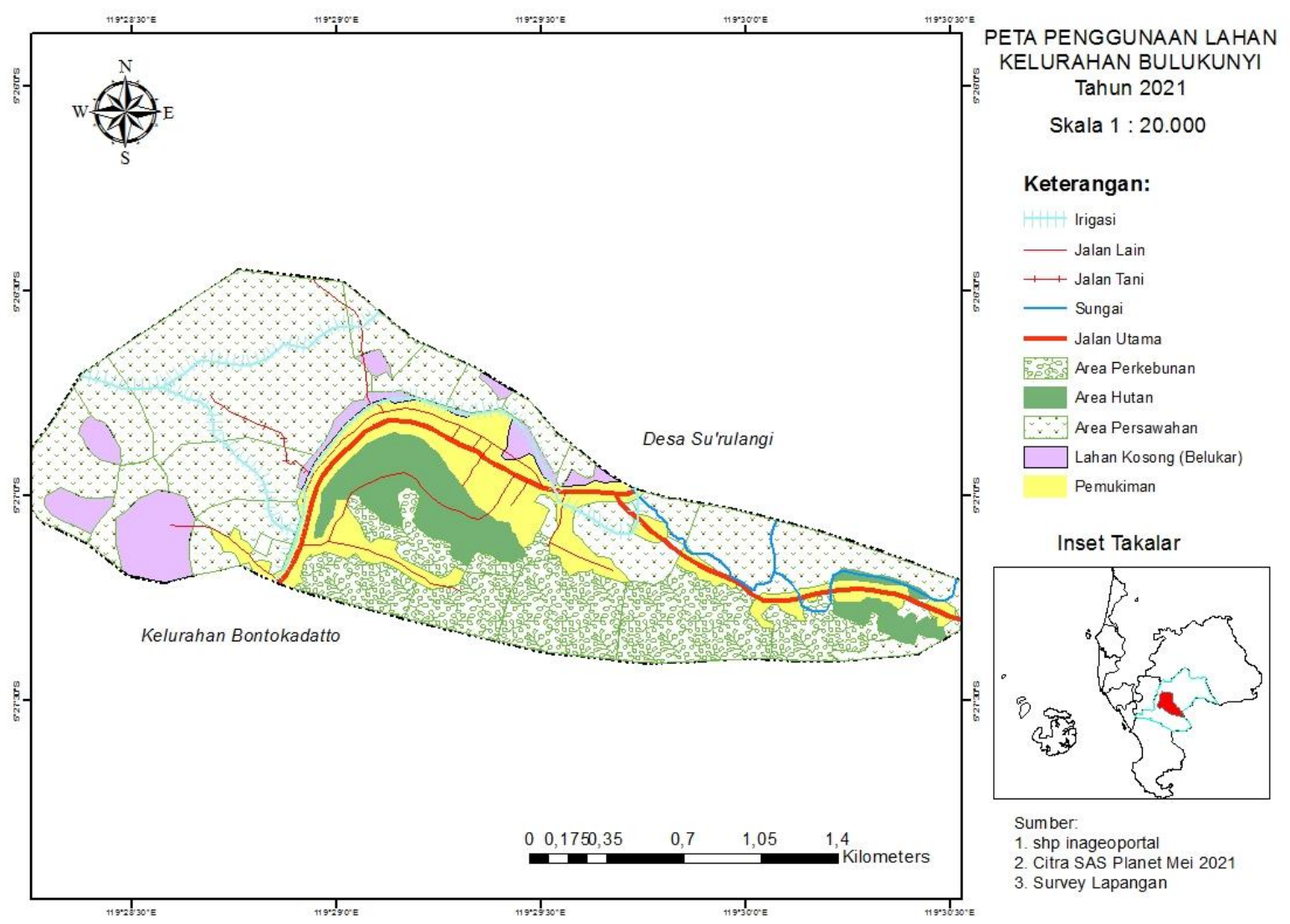

Sumber: Citra SAS Planet dan Survey lapangan, Mei 2021

Gambar 5. Peta Penggunaan Lahan Kelurahan Bulukunyi

Di bagian barat merupakan area persawahan yang cukup luas hingga sebagian wilayah utara. Area ini dimanfaatkan untuk tanaman padi pada musim hujan sedangkan pada musim kemarau ditanami kacang-kacangan. Bagian selatan di dominasi oleh area perkebunan yang sifatnya heterogen antara lain tanaman jangka panjang seperti jambu mete, dan mangga serta tanaman jangka pendek seperti jagung dan umbi-umbian. Area permukiman berada pada bagian tengah memanjang mengikuti jalan utama dan jalan lokal. Pada area hutan ditemui beragam jenis tanaman tingkat tinggi seperti jati, mahoni, akasia, nangka, dan sebagainya. Terdapat sungai yang mengalir dari timur ke barat serta saluran irigasi yang mengalir ke area persawahan.

\section{Kesimpulan}

Permukiman penduduk di Kelurahan Bulukunyi memiliki pola memanjang atau linier mengikuti jalan utama atau jalan lokal. Pusat-pusat kegiatan di Kelurahan Bulukunyi 
berada pada bagian tengah dan pengembangannya mengikuti keberadaan jalur transportasi. Fasilitas publik tersedia antara lain fasilitas perkantoran, kesehatan, ekonomi, pendidikan, dan ibadah. Penggunaan lahan didominasi lahan pertanian sehingga Kelurahan ini masih dikategorikan sebagai desa agropolitan.

\section{Referensi}

Alfandi, Widoyo. 2001. Epistemologi Geografi. Yogyakarta. Gadjah Mada University Press.

Farida, Umrotul. 2013. Pengaruh Aksesibilitas Terhadap Karakteristik Sosial Ekonomi Masyarakat Pedesaan Kecamatan Bumijawa Kabupaten Tegal. Jurnal Wilayah dan Lingkungan. Volume 1 Nomor 1, April 2013, 49-66.

Magribi, La Ode Muhammad \& Suhardjo, Aj. 2007. Aksesibilitas Dan Pengaruhnya Terhadap Pembangunan $\mathrm{Di}$ Perdesaan: Konsep Model Sustainable Accessibility Pada Kawasan Perdesaan Di Propinsi Sulawesi Tenggara. Jurnal Transportasi Vol. 4 No. 2 Desember 2004: 149-160.

Muta'ali, Lutfi. 2016. Pengembangan Wilayah Perdesaan (Perspektif Spasial). Yogyakarta. Badan Penerbit Fakultas Geografi Universitas Gadjah Mada.

Peraturan Pemerintah Nomor 72 Tahun 2005 Tentang Desa

Peraturan Pemerintah Nomor 73 Tahun 2005 Tentang Kelurahan

Prasad, Abdul Hallaf Hanafie. 2013. Mengamati Fenomena Geografi. Yogyakarta. Digna Pustaka.

Rudiarto, Iwan dkk. 2017. Pola Ruang Lansekap Pedesaan: Penilaian Perubahan Guna Lahan Dengan Indeks Vegetasi Di Pedesaan Jawa Tengah. Jurnal Tata Loka, Volume 19 Nomor 4, November 2017, 280-290.

Suharyono \& Amin, Moch. 2013. Pengantar Filsafat Geografi. Yogyakarta. Ombak. Surachman, Shidik. 2012. Analisis Struktur Ruang Kota Kecamatan (Studi Kasus: Kecamatan Jatitujuh Kabupaten Majalengka). Bandung. Skripsi. Program Studi Perencanaan Wilayah dan Kota . Fakultas Teknik dan Ilmu Komputer Universitas Komputer Indonesia.

Tarigan, Robinson. 2005. Ekonomi Regional. Jakarta. Bumi Aksara.

Undang Undang Republik Indonesia No. 32 Tahun 2004 tentang Pemerintah Daerah Yunus, Hadi Sabari. 2010. Metodologi Penelitian Wilayah Kontemporer. Yogyakarta. Pustaka Pelajar. 